\title{
Piotr Andrzejewski
}

Instytut Studiów Politycznych PAN

\section{Rosyjskie wpływy w Austrii po kryzysie na Ukrainie w 2014 roku}

\section{Wstęp}

Austria jest krajem relatywnie małym. Jednakże ta alpejska republika na dyplomatycznej mapie świata stanowi jeden z najważniejszych punktów. Swą pozycję zawdzięcza neutralności w czasach zimnej wojny, gdy Wiedeń stanowił jeden z bardziej znaczących punktów spotkań pomiędzy Wschodem i Zachodem oraz arenę walk wywiadów. Wiedeń po dziś dzień stanowi jedno z czterech miejsc na świecie, obok Nowego Jorku, Genewy i Nairobi, gdzie umiejscowione są instytucje ONZ. Znajdują się tam również siedziby OBWE oraz OPEC. Specyficzna rola tego kraju jako centrum dyplomatycznego była rezultatem polityki aliantów z czasów II wojny światowej. W 1943 roku na konferencji w Moskwie USA, ZSRR i Zjednoczone Królestwo uznało Austrię za pierwszą ofiarę hitlerowskiej agresji. Deklaracja ta miała fundamentalne znaczenie dla powojennych losów alpejskiej republiki. Uznanie jej za ofiarę oznaczało, że Austria w przeciwieństwie do Niemiec miała zostać nie podbita, a wyzwolona. Zarówno Amerykanie, Anglicy, Francuzi, jak i Sowieci byli traktowani jak wyzwoliciele ratujący kraj przed nazistowską okupacją. Do dziś w centrum Wiednia stoi złoty pomnik żołnierza Armii Czerwonej - bohatera i wyzwoliciela. Od 1955 roku i Państwowego Traktatu siły sojusznicze wycofały się z terytorium Austrii w zamian za jej neutralność. Potrzeba balansowania pomiędzy wpływami Wschodu i Zachodu powodowała, że kolejne rządy Austrii musiały utrzymać dobre stosunki nie tylko z przywódcami państw demokratycznych, ale także, a może przede wszystkim, z państwami bloku wschodniego. W przeciwieństwie do Zachodu Austria nie musiała zajmować pozycji antagonistycznych wobec ZSRR i wykorzystywała tę sytuację do zachowania szczególnych relacji z Sowietami. 
Tradycja dobrych kontaktów ze wschodem utrzymywana jest do dziś, a Austria stanowi jedno z najbardziej prorosyjskich państw europejskich. Ta sytuacja ma szczególny wpływ na zachowanie się Austrii po rosyjskiej agresji na Krym oraz interwencji na wschodniej Ukrainie. Jednocześnie Austria jest na czele tych państw, w których wpływy rosyjskie były i są bardzo silne. Jest to zjawisko o tyle ciekawe, że dla Austrii Rosja nie jest praktycznie żadnym znaczącym partnerem handlowym, zajmując kolejno 22 drugie miejsce jako importer i 24 jako eksporter ${ }^{1}$. Oznacza to, że nie więzi gospodarcze, ale więzi historyczne i polityczne grają $\mathrm{w}$ austriacko-rosyjskich relacjach pierwsze skrzypce. Obserwując rosnące napięcia pomiędzy Rosją a szeroko pojętym Zachodem, w szczególności po ostrej dyplomatycznej reakcji na próbę zabójstwa Siergieja Skripala, uderza reakcja Austrii. Alpejska republika nie tylko nie wydaliła żadnego rosyjskiego dyplomaty w geście solidarności z Wielką Brytanią, ale wyszła przed szereg i zaproponowała przeprowadzenie mediacji $\mathrm{w}$ tej trudnej sprawie. Warto przeanalizować przypadek Austrii, pokazać, skąd bierze się tak specyficzne podejście do Rosji i ocenić skalę rosyjskich wpływów w tym kraju.

Poniższa analiza stanowi punkt wyjścia do badań komparatystycznych dyskursu w poszczególnych państwach europejskich. Analiza dyskursu oparta jest na zaproponowanej przez Ruth Wodak analizie tekstu, umieszczonej na kilku poziomach kontekstów. Wyszczególnia ona cztery takie poziomy:

1) językowy (tekstowy);

2) międzytekstowy, interdyskursywny związek między dyskursami;

3) socjologiczne i instytucjonalne ramy (mezokontekst);

4) szerszy kontekst społeczny, polityczny i historyczny².

Nie chcąc wchodzić w definicję tekstu oraz kwestię interdyskursywności, która $\mathrm{w}$ tej analizie nie ma większego znaczenia, ograniczę się do bardziej politologicznego niż socjologicznego badania, skupiając się przede wszystkim na najwyższym i najszerszym kontekście funkcjonowania wypowiedzi i tekstów, czyli na wymiarze politycznym i międzynarodowym. Jest to najwłaściwsze ujęcie - zarówno język dyplomacji, jak i kontaktów międzynarodowych ma swoją ugruntowaną historycznie specyfikę.

\section{Specjalne relacje}

Austria i Rosja posiadają długą historię wzajemnych przyjaznych stosunków. Geopolityczne położenie obu państw często doprowadzało do ich współpracy. Austria nie należy do grona najznaczniejszych europejskich krajów, jednakże specyficzne relacje z Niemcami, położenie w sercu Europy Środkowej i wpływy na Bałkanach czynią z Austrii atrakcyjnego partnera. Rosja i Austria nie posiadają także żadnych przeciwstawnych interesów geopolitycznych. Historycznie współpraca obu państw rozwijała się najsilniej od połowy XVIII do połowy XIX wieku. Natomiast największym kryzy-

\footnotetext{
1 https://wits.worldbank.org/CountryProfile/en/Country/AUT/Year/2015/TradeFlow/EXPIMP/ Partner/by-country (dostęp: 7 lutego 2018).

2 R. Wodak, Dyskurs populistyczny: retoryka wykluczenia a gatunki języka pisanego, thum. J. Wawrzyniak i A. Wójcicki, w: A. Duszak i N. Fairclough (red.), Krytyczna analiza dyskursu, Universitas, Kraków 2008, s. 185-214.
} 
sem był czas dwóch wojen światowych, gdy Austria była po stronie państw centralnych i jako część państw Osi. Przyjazna specyfika austro-rosyjskich relacji powróciła na stare tory dopiero po zakończeniu II wojny światowej. Austria została potraktowana inaczej niż Niemcy - jako pierwsza ofiara hitlerowskiej agresji. $Z$ tego powodu kraj ten nie odczuwa rosyjskiego zagrożenia tak jak inne kraje Europy Środkowej, co najlepiej symbolizuje pomnik żołnierza Armii Czerwonej w samym centrum Wiednia. Pozłacana figura czerwonoarmisty jest traktowana jako upamiętnienie bohaterów i wyzwolicieli, a nie jako symbol najeźdźców.

Kooperacja obu państw zasadza się na dwóch filarach: Austrii jako centrum przesyłowego rosyjskiego gazu do państw Europy Zachodniej oraz na inwestycjach austriackiego sektora bankowego w Rosji. Z tego powodu Austria wspiera budowę gazociagu South Stream, który docierałby do miejscowości Baumgarten. Alpejska republika stanowi także przystań dla rosyjskiego kapitału, a Sbierbank posiada siedzibę w Wiedniu. Do tego opisu należy dołożyć wymiar europejski. Austria krytykuje program Partnerstwa Wschodniego jako wymierzony w Rosję i apeluje o jego zmianę, jednocześnie kraj ten nie jest adwokatem przyjęcia Ukrainy w struktury unijne.

Kiedy 21 listopada 2013 roku na placu w Kijowie rozpoczęły się protesty przeciwko niepodpisaniu umowy stowarzyszeniowej z Unią Europejską przez prezydenta Ukrainy Wiktora Janukowycza, nikt nie mógł przewidzieć, jak dramatyczny bieg przybiorą wydarzenia. Bohaterska postawa protestujacych na tzw. Euromajdanie oraz reakcja innych państw spowodowała ucieczkę Janukowycza z Ukrainy, zmianę rządów i obranie przez to państwo prozachodniego kursu. Reakcja wschodniego sąsiada Ukrainy, czyli Rosji, była zdecydowana. Na przełomie lutego i marca 2014 roku Rosjanie dokonali aneksji półwyspu krymskiego W kwietniu 2014 roku rozpoczęli tzw. wojnę hybrydową przeciwko Ukrainie. W obwodzie ługańskim i donieckim separatyści inspirowani i zaopatrywani przez Rosję doprowadzili do powstania samozwańczych republik ludowych i destabilizacji wschodniej Ukrainy. W reakcji na te działania, które stanowiły jawne pogwałcenie prawa międzynarodowego i traktatów, których stroną była także Rosja, państwa Unii Europejskiej oraz USA nałożyły na Rosję sankcje, które trwają do dnia dzisiejszego (stan na marzec 2018).

Charakterystyka wojny hybrydowej prowadzonej przez Rosję pozwala jej częściowo uniknąć odpowiedzialności za agresję. Ta strategia wojenna łączy działania konwencjonalne, nieregularne i cybernetyczne. Nie ogranicza się tylko do państwa, które pada ofiarą takiej zakamuflowanej agresji. Rosja stara się wpływać na postawę obywateli i państw Zachodu poprzez dezinformację oraz przesunięcia akcentów w dyskursie publicznym. Mówi się nawet o tak radykalnych posunięciach jak próby wpływania na rezultaty wyborów w poszczególnych państwach. Tak zwana inwazja internetowych „trolli”, czyli osób w mniej lub bardziej wyrafinowany sposób przejmujących dyskusję i komentarze w mediach społecznościowych i forach jest faktem. W tym kontekście najbardziej zasłynęła „fabryka trolli” znajdująca się pod Petersburgiem, w której kilka tysięcy osób zajmuje się pisaniem komentarzy w internecie w różnych językach.

Oczywiście rosyjskie wpływy nie kończą się tylko na próbach wpływania na dyskurs publiczny w poszczególnych państwach. Istnieją również bardziej tradycyjne powiązania: gospodarcze, finansowe czy polityczne. Jak zatem wygląda sytuacja w Austrii, kra- 
ju tradycyjnie bardziej otwartym na rosyjskie wpływy? Po pierwsze należy przeanalizować, jaką narrację Rosja próbuje wypromować nad Dunajem, by następnie przyjrzeć się, jakie są instytucjonalne i personalne wpływy tego państwa w Austrii.

\section{Dunajski front wojny narracyjnej}

Jednym z najważniejszych dokumentów zbierających i analizujących oblicza narracyjnej agresji Rosji jest raport Fundacji Konrada Adenauera z maja 2014 roku, a więc z okresu silnej aktywności „rosyjskich dywizji internetowych”. Najważniejsze zworniki rosyjskiej narracji wymierzonych w Ukrainę można streścić w dziesięciu punktach, czy też jak nazywa je raport, w dziesięciu mitach.

1. Zachód interweniował i mieszał się do wewnętrznych spraw Ukrainy. Jest bezpośrednio odpowiedzialny za wywołanie protestów na Majdanie przy pomocy faszystowskich ugrupowań.

2. Przejściowy rząd w Kijowie doszedł do władzy na drodze zamachu stanu i jest nielegalny.

3. Etniczni Rosjanie, którzy żyją głównie we wschodniej i południowej Ukrainie, są prześladowani przez rząd i faszystów.

4. Uzbrojeni separatyści na południu i wschodzie Ukrainy to siły samoobrony, które chca przyłączenia do Federacji Rosyjskiej.

5. Rząd w Kijowie walczy przeciwko własnej populacji na wschodzie i thumi pokojowe protesty.

6. Przez wzgląd na historię oraz powiązania etniczno-kulturowe Ukraina należy do naturalnej strefy wpływów i może cieszyć się tylko ograniczoną suwerennością.

7. Prawo do samostanowienia ludów na drodze referendów legitymizuje secesję Krymu i innych terytoriów oraz ich przyłączenie się do Federacji Rosyjskiej.

8. Zachód stosuje podwójne standardy w ocenie sytuacji Kosowa i Krymu.

9. Po rozpadzie ZSRR Zachód prowadził politykę tłamszenia i osłabiania Rosji.

10. Pomimo wcześniejszych obietnic NATO rozszerzyło swoją strefę wpływów na terytorium państw byłego bloku wschodniego i w ten sposób narusza bezpieczeństwo Federacji Rosyjskiej³.

Do powyższych tez należy także dołożyć bardziej ukierunkowane na Austrię mity, które zebrała Aleksandra Sajenko z ukraińskiej ambasady w Wiedniu:

1. Nie ma jednego narodu ukraińskiego, istnieją Ukraińcy Zachodni (mieszkający na terytorium wcześniej wchodzące w skład C.K. Monarchii) oraz Wschodni Ukraińcy, którzy należeli do Rosji.

2. Noworosja to termin umocowany $\mathrm{w}$ historii, a jego terytorium pokrywa się ze wszystkim wschodnimi i południowymi regionami Ukrainy.

3. Ci, którzy krytykują politykę Putina, są rusofobami na smyczy Amerykanów i faszystami.

3 Raport Konrad Adenauer Stiftung, Zehn Mythen der Rechtfertigung russischer Politik in der Ukraine-Krise, http:/www.kas.de/wf/doc/kas_37844-544-1-30.pdf?140527172529 (dostęp: 7 lutego 2018). 
4. Ukraińscy oligarchowie walczą o swoje wpływy i Austria nie powinna uczestniczyć w tym wewnętrznym konflikcie.

5. Austria nie powinna poświęcać swoich długofalowych i rozbudowanych kontaktów i relacji z Rosją ze względu na słabe i skorumpowane państwo, jakim jest Ukraina.

6. Zachód (UE i USA) walczą przeciwko Rosji, a Ukraina jest jedynie ich bezwolnym narzędziem w tej walce.

7. Sankcje nałożone na Rosję nie są efektywne i szkodzą austriackiej gospodarce ${ }^{4}$.

Wiele z powyższych mitów, które są propagowane przez rosyjskie media czy rosyjską aktywność w mediach społecznościowych, zostało podchwyconych przez naczelnych austriackich polityków, co skutkowało tym, że narracja ,wyprodukowana” w Rosji stała się częścią austriackiego dyskursu politycznego. Już w 2014 roku, a więc w czasie największego kryzysu, zajęcia Krymu oraz hybrydowej agresji na Ukrainę, prezydent Rosji Władimir Putin udał się z oficjalną wizytą do Wiednia, gdzie został przywitany z honorami. Podkreślano rolę gospodarczych powiązań pomiędzy dwoma państwami oraz tradycyjną rolę neutralnej Austrii: mostu między narodami, miejsca spotkań i dyskusji. Ówczesny prezydent Austrii Heinz Fischer opowiedział się przeciwko nakładaniu sankcji na Rosję. Jednakże najważniejsze zdania padły podczas wieczornego spotkania w Izbie Handlowej. Prezydent Putin podkreślał strategiczne znaczenie udziału austriackiej firmy ÖMV w budowie gazociagu South Stream, który nie jest wymierzony w nikogo i który został nazwany sposobem na osiagnięcie stabilności w Europie. Z kolei przewodniczący Izby Handlowej Christoph Leitl mówił: „Krytycy tego spotkania twierdzili, że ekonomiczne interesy znowu wchodzą w paradę problemom politycznym. Lecz ja pytam: czy działalność gospodarcza nie pomaga rozwiązywać problemów politycznych? Istnieją ludzie, którzy domagają się sankcji gospodarczych. Ja pytam: czy to rozwiąże problemy, czy je pogłębi? Czy sankcje służą ludziom, czy im szkodzą? Dla mnie odpowiedź jest jasna"6.

Politycy dwóch głównych partii starają się zachować dyplomatyczny dystans wobec sankcji nałożonych na Rosję przy jednoczesnym podkreślaniu znaczenia austriacko-rosyjskich relacji gospodarczych. Jednakże to nie SPÖ czy ÖVP stanowią najbardziej prorosyjskie ugrupowanie na austriackiej scenie politycznej. Palma pierwszeństwa należy do tzw. trzeciego obozu, liberalnej partii FPÖ. Pod koniec 2016 roku delegacja Wolnościowej Partii Austrii udała się z wizytą do Moskwy, gdzie podpisana została umowa o współpracy z największą rosyjską partią Jedna Rosja ${ }^{7}$. Jest to pierwszy przypadek

\footnotetext{
4 A. Sajenko, Austria. Those who understand Putin outnumber those who can understand Ukraine, http://english.gordonua.com/news/exclusiveenglish/austria-those-who-understand-putin-outnumber-those-who-can-understand-ukraine-63468.html (dostęp: 7 lutego 2018).

5 E. Henckel, Die seltsame Russland-Liebe der Österreicher, https://www.welt.de/politik/ ausland/article129432474/Die-seltsame-Russland-Liebe-der-Oesterreicher.html (dostęp: 7 lutego 2018)

$6 \quad$ Neue Seite in den Beziehungen Russlands und Österreichs, https://de.sputniknews.com/german.ruvr.ru/2014_06_25/Neue-Seite-in-den-Beziehungen-Russlands-und-Osterreichs-4841/ (dostęp: 7 lutego 2018).

A. Mills, Austria's far-right seals pact with Russia, https://euobserver.com/beyond-brussels/136356 (dostęp: 7 lutego 2018).
} 
kooperacji europejskiej partii z ugrupowaniem Władimira Putina. Najprawdopodobniej widząc słabnące wpływy dwóch tradycyjnie najbardziej znaczących partii w Austrii: socjaldemokratów i ludowców, strona rosyjska zdecydowała się rozwinać kontakty z coraz bardziej rosnącą na znaczeniu partią wolnościową. Inwestycja w kontakty z FPÖ opłaciła się. Dziś partia ta współtworzy rząd kanclerza Sebastiana Kurza, obejmując m.in. Ministerstwo Spraw Zagranicznych.

Podpisanie umowy o współpracy między między FPÖ a Jedną Rosją stanowi punkt kulminacyjny współpracy, która trwa od ponad dekady. Poprzedni lider wolnościowców, Jörg Haider (zginął w wypadku samochodowym w 2008 roku), nawiązał kontakty z despotami, takimi jak Muammar Kadaffi czy Saddam Husajn. Właśnie za prezesury Haidera rozpoczęto partyjne kontakty z Rosja, chociaż miały one bardzo powierzchowny charakter. Przełom miał nadejść wraz z objęciem przewodnictwa w FPÖ przez Heinza-Christiana Strache po rozpadzie w partii w 2005 roku. Kontakty z Rosjanami zaczęli utrzymywać najwyżsi rangą oficjele FPÖ, w tym wspomniany Strache, przewodniczący partyjnej komisji spraw zagranicznych Johann Gudenus, poseł Johannes Hübner czy były kandydat na prezydenta Norbert Hofer (otrzymał 35\% głosów w pierwszej turze, a następnie $49 \% \mathrm{w}$ drugiej). Ze strony rosyjskiej za kontakty odpowiada religijny i konserwatywny oligarcha Konstantin Małofiejew ${ }^{8}$. W 2014 roku Małofiejew zorganizował w Wiedniu spotkanie ruchów określanych jako radykalnie prawicowe. Przywoływał on podczas tego spotkania ducha „Świętego Przymierza”, czyli koalicji Austrii, Prus i Rosji zwalczających ruchy rewolucyjne w XIX-wiecznej Europie. „Starym-nowym" wrogiem określił on siły lewicy, sekularyzujące i niszczące tradycyjne wartości oraz wskazał na kolejne zagrożenie ze strony świata islamu, czyli napływ imigrantów i terroryzm. Jednym z wyrazów ideowej wspólnoty jest dystansowanie się lub krytyka środowisk LGBT. Zarówno Małofiejew, jak i Gudenus, choć w innym stylu, krytykują Unię Europejską jako siedlisko sodomitów lub homoseksualne lobby9. Małofiejew nazwał występ Conchity Wurst (zwycięzcy Eurowizji w 2015 roku, transseksualnego artysty reprezentującego Austrię) jako wysłanie zboczeńców na konkurs piosenki. Władimir Żyrinowski określił zwycięstwo Conchity jako koniec Europy. Dodał również w tym kontekście, że sowieckie wojska nigdy nie powinny były opuścić Austrii. W podobnym tonie wypowiadał się Johann Gudenus, nazywając Unię homoseksualnym lobby.

Jak widać, rosyjska narracja jest przyjmowana w Austrii wielopłaszczyznowo. Partie głównego nurtu skupiają się na ekonomicznych aspektach współpracy z Rosją, natomiast radykalna prawica podkreśla wspólnotę wartości oraz zagrożenia dla cywilizacji, takie jak: sekularyzacja, zbytnia progresywność, napływ imigrantów itd. Aleksandra Sajenko wskazuje na fakt, że większość komentatorów życia publicznego propaguje ideę nieangażowania się Austrii w konflikt na Ukrainie. Istnieje również ogromna dysproporcja pomiędzy ukraińskimi możliwościami wpływania na obieg informacji w alpej-

\footnotetext{
Małofiejew opowiada się także za finansowaniem rosyjskich agentów wpływu w Polsce, http:// niezalezna.pl/94739-zdrajcy-polski-na-pasku-kremla-tak-raportowali-do-moskwy-nowe-fakty (dostęp: 7 lutego 2018).

9 Gudenus Kritisiert in Moskau EU, NATO und 'Homosexuellenlobby, http://derstandard.at/ 2000005507900/Vortrag-in-Moskau-Gudenuskritisiert-EU-NATO-und-Homosexuellenlobby (dostęp: 7 lutego 2018).
} 
skiej republice. Najważniejszy wschodni korespondent państwowej telewizji ORF Christian Wehrschütz, zdobywca tytułu dziennikarza roku, potrafił udostępniać na swoich profilach społecznościowych informacje preparowane przez Russia Today. Czynił to bez żadnego przypisu lub komentarza. Jego profil był także świadkiem licznych antyukraińskich wypowiedzi i dyskusji ${ }^{10}$.

Inną postacią siejącą dezinformację jest Klaus Pridnig, austriacki producent filmowy powtarzający tezy o Angeli Merkel sponsorującej neonazistów w Ukrainie czy popierający separatystów w Donbasie jako samoobronę przed neonazistami z Prawego Sektora i partii Swoboda. Biorąc pod uwage niskie zainteresowanie austriackich dziennikarzy kwestią ukraińską oraz fakt, że austriackie media nie mają stałego korespondenta na Ukrainie powoduje, że Wehrschütz czy powiązany finansowo z Ukrainą Pridnig stanowią dominujące źródło informacji. Co prawda sporadycznie pojawiają się głębsze analizy na łamach prasy głównego nurtu i należy wspomnieć, że zarówno „PROFIL”, „Die Presse” czy „Kurier” nie mają problemów z określeniem putinowskiej Rosji jako głównego prowodyra i sprawcy w konflikcie w Ukrainie. Inaczej sprawa ma się w internecie, w którym dominują prorosyjscy blogerzy i komentatorzy. Rosyjski dyplomata z wiedeńskiej ambasady w 2014 roku skrytykował nawet jednostronne przedstawianie Rosji w austriackich mediach i wyraził nadzieję, że alternatywne media w internecie pokażą dużo bardziej zrównoważony obraz ${ }^{11}$. Istotnie rosyjska aktywność koncentruje się właśnie w internecie. Przynajmniej na tym odcinku dunajskiego frontu rosyjska ofensywa narracyjna odnosi spore sukcesy. Inny odcinek stanowi prasa powiązana z radykalna prawica. Tytuły takie jak sprzyjająca FPÖ „Die Aula” czy „Zur Zeit” i fundamentalistyczny „Neue Ordnung” stanowią naturalne środowisko do promowania prorosyjskich i antyukraińskich treści. Jednocześnie luźno powiązana z FPÖ bulwarowa gazeta „Kronen Zeitung" jest czasopismem nastawionym antyimigrancko i eurosceptycznym i zdarza się, choć nie programowo, przekazywać proputinowskie treści. „Kronen Zeitung” jest największą gazetą w Austrii o nakładzie wahającym się między 800 tys. i milionem egzemplarzy, docierając do trzech z ośmiu milionów Austriaków.

\section{Główne ośrodki rosyjskich wpływów}

Austriacko-węgierski zespół badaczy pod auspicjami fundacji National Endowment for Democracy opublikował raport o rosyjskich koneksjach radykalnej prawicy w Austrii. Nie ulega wątpliwości, że środowisko „trzeciego obozu” - radykalnie prawicowej partii FPÖ jest najsilniej powiązane z Rosją. Jednak autorzy przy tej okazji starali się stworzyć wykaz wszystkich możliwych instytucji ulegających rosyjskim wpływom ${ }^{12}$. Poza trzema głównymi partiami SPÖ, ÖVP i FPÖ raport wymienia także WKÖ - Fede-

\footnotetext{
10 Those who understand Putin outnumber those who can understand Ukraine, http://english. gordonua.com/news/exclusiveenglish/austria-those-who-understand-putin-outnumber-those-whocan-understand-ukraine-63468.html (dostęp: 2 lutego 2018).

11 Russische Botschaft Beklagt Österreichs Einseitige Medienberichterstattung, http://derstandard.at/1397521268304/Russische-Botschaft-beklagt-Oesterreichs-einseitige-Berichterstattung (dostęp 2 lutego 2018).

12 G. Lóránt (red.), Russian Connections of the Austrian Far-right, Budapest 2017, s. 22-42.
} 
ralną Izbę Gospodarczą ÖRFG - Austriacko-Rosyjskie Towarzystwo Przyjaźni, ÖIAG - Austriacki Holding Przemysłowy, IBÖ - Austriacki Ruch Identytarystów, Instytut Suworowa oraz media internetowe: unzensuriert.at, Info-DIREKT i Pegida Österreich.

O dwóch głównych partiach była już mowa powyżej. Należy jednak poszerzyć ich opis, tak by uwzględniał ich oficjalne stanowisko dotyczące rosyjskiej agresji na Ukrainie. Socjaldemokraci popieraja zniesienie sankcji, ale tylko pod warunkiem realizacji porozumień z Mińska. W łonie partii istnieje mniejszościowa grupa polityków domagających się natychmiastowego zniesienia sankcji, jednym z nich jest były kanclerz Alfred Gusenbauer ${ }^{13}$. SPÖ można określić jako najmniej proputinowską partię na austriackiej scenie politycznej.

ÖVP jest dużo bardziej aktywna w swojej krytyce sankcji nałożonych na Rosję. Stanowisko ÖVP thumaczone jest gospodarczym pragmatyzmem. Reinhold Mitterlehner prezes ÖVP i minister gospodarki otrzymał Order Przyjaźni Federacji Rosyjskiej w 2016 roku. Nie bez znaczenia jest również fakt, że zgodnie z tradycyjnym podziałem miejsc w instytucjach publicznych przez dwie główne partie w Austrii (tzw. Proporzsystem) politycy partii konserwatywno-ludowej najczęściej otrzymywali posady w WKO - Federalnej Izbie Gospodarczej. Wspomniany i cytowany powyżej Christian Leitl przewodniczący Izby Gospodarczej jest właśnie politykiem ÖVP. Wielokrotnie apelował on o zniesienie sankcji nałożonych na Rosję, by umożliwić rozwój wymiany handlowej. Biorąc pod uwagę silniejsze powiązania ludowców z kręgami biznesowymi i przedsiębiorcami, nie dziwi, że większość członków partii stoi na stanowisku, że sankcje szkodzą Austrii. Kraj traci na ograniczeniach w handlu oraz przede wszystkim na mniejszej liczbie turystów z Rosji.

Biznesowe powiązania pojawiają się również w kolejnej instytucji wspomnianej w raporcie, tj. ÖRFG - Austriacko-Rosyjskie Towarzystwo Przyjaźni. Grupuje ono postaci takie jak Ludwig Scharinger, wyższy rangą pracownik Banku Raiffeisen, prezes zajmującej się handlem i dystrybucją ropy naftowej firmy ÖMV Richard Schenz oraz Siegfried Wolf, osobisty przyjaciel Władimira Putina i prezesa rady nadzorczej ÖIAG - Austriackiego Holdingu Przemysłowego. W Towarzystwie Przyjaźni działają także mniej lub bardziej znaczący politycy wszystkich partii (w tym wspomniany działacz FPÖ Johann Gudenus). Od czasów kryzysu krymskiego ORFG jako organizacja zyskała na znaczeniu jako krytyk sankcji.

Powyższe zestawienie dobitnie pokazuje ekonomiczny charakter działań partii głównego nurtu, szeregu instytucji państwowych oraz poszczególnych przedsiębiorstw. Dopiero w kontakcie z radykalną prawica - współpraca z Rosją staje się dużo głębsza i wchodzi w świat wartości. Taka sytuacja jest o tyle ciekawa, że przez większą część swojej historii tzw. trzeci obóz, czyli FPÖ kontynuowała tradycje niemiecko-narodowe, nie uznawała narodu austriackiego za odrębny od niemieckiego, a jako swojego największego ideowego wroga traktowała komunizm. Ta niechęć do komunizmu przemieszana była z rasistowskim antyslawizmem, który był przede wszystkim wymierzony w Rosję. Podejście radykalnej prawicy do Rosji zaczęło się zmieniać wraz z upad-

13 Kritik: Ex-Bundeskanzler Gusenbauer Kritisiert EU-Sanktionen Gegen Russland, https://kurier.at/politik/ausland/kritik-ex-bundeskanzler-gusenbauer-kritisiert-eu-sanktionen-gegen-russland/88.166.578 (dostęp: 7 lutego 2018). 
kiem ZSRR i potwierdzeniem światowej hegemonii Stanów Zjednoczonych. Od lat dziewięćdziesiątych XX wieku coraz częściej podkreślano niechęć do „amerykańskiego imperializmu". Jednocześnie Rosja krok po kroku pokazywała ideowe pokrewieństwo z partiami radykalnej prawicy w całej Europie w kwestiach takich jak: tożsamość, religia czy zagrożenie ze strony islamu. Również same kontakty na linii FPÖ - Rosja nie pojawiły się od razu. Jörg Haider, który przewodniczył Austriackiej Partii Wolnościowej, choć lubił skandalizować i przebywać w towarzystwie autokratów, nie rozwinął szerszych kontaktów ze środowiskiem Władimira Putina. Przełomem był rozpad FPÖ w 2005 i śmierć Haidera w roku 2008. Kiedy ten karyncki polityk założył własną partię BZÖ kierownictwo w FPÖ objął młody Heinz-Christian Strache. Już w 2007 roku Małofiejew założył Fundację św. Bazylego Wielkiego, która stanowi ośrodek spotkań prawicowych ekstremistów z całej Europy. W 2009 roku powiązane ideowo z FPÖ korporacje studenckie (Burschenschaften) zaprosiły do Austrii na Akademikerball kremlowskiego ideologa - twórcę wielkoruskiej i imperialistycznej wizji stanowiącej podparcie reżimu Władimira Putina. Bal akademików do dziś stanowi miejsce spotkań polityków i sympatyków ruchów radykalnie prawicowych. W 2014 roku fundacja św. Bazylego Wielkiego potajemnie zorganizowała w Wiedniu zjazd prawicowych ekstremistów. Wśród gości byli m.in. Heinz-Christian Strache, Johann Gudenus, Marion Marechal-Le Pen (siostrzenica liderki francuskiego Frontu Narodowego Marine) oraz Wolen Siderow, założyciel bułgarskiej partii Ataka. Gościem specjalnym był Aleksander Dugin.

Ze wszystkich uczestników wiedeńskiego spotkania wyróżnia się Johann Gudenus. Postać ta jest najbardziej aktywnym łącznikiem pomiędzy FPÖ a Rosją, dlatego warto przyjrzeć mu się trochę bliżej. Pochodzi on z rodziny o silnych powiązaniach z nazizmem (jego ojciec został skazany za działalność w NSDAP w czasie II wojny światowej), Johann urodził się w 1976 roku i z polityką związał się szybko, wstępując do młodzieżówki FPÖ, od 2005 roku zasiadał także w wiedeńskim parlamencie. Swoje zainteresowanie Rosją thumaczy sprawami sercowymi - miał zakochać się w Rosjan$\mathrm{ce}^{14}$. Miłością do kobiety nie da się jednak wytłumaczyć jego wizyt w szkołach letnich organizowanych przez Uniwersytet Łomonosowa w latach 1994-2003, czyli w czasie przed romansem. W 2005 roku zakończył studia w prestiżowej Wiedeńskiej Akademii Dyplomatycznej. Co ważniejsze, uczestniczył także w kursie prowadzonym przez Akademię Dyplomatyczną Ministerstwa Spraw Zagranicznych Federacji Rosyjskiej. Szkoła została założona w 1934 roku do przygotowania sowieckiego korpusu dyplomatycznego i jednocześnie agentury dyplomatycznej. Szkoła ta po kilku strukturalnych zmianach po upadku ZSRR działa do dziś.

Johann Gudenus wraz z innym politykiem FPÖ Johannesem Hübnerem byli obserwatorami referendum na Krymie ${ }^{15}$. W następnej wizytacji na Krymie uczestniczyli kolejni członkowie FPÖ Jörg Jenewein i Detlef Wimmer. Ich obecność na półwyspie krymskim

14 S. Khomenko, FPÖ: Aus Liebe Zu Russland, http://mokant.at/1506-fpoe-russland-ukrainegeld/ (dostęp: 7 lutego 2018).

15 Krim-Beobachter: FPÖ-Abgeordnete von Moskauer Agenturen Vermittelt, https://www.profil. at/oesterreich/krim-beobachter-fpoe-abgeordnete-moskauer-agenturen-373711 (dostęp: 7 lutego 2018). 
skrytykował ukraiński ambasador w Austrii Oleksandr Scherba, twierdząc, że działanie to naruszyło neutralność Austrii i prawo Unii Europejskiej ${ }^{16}$. Gudenus miał także swoje pięć minut jako obserwator wyborów municypalnych w Rosji. We wrześniu 2014 roku nie dopatrzył się żadnych uchybień podczas wyborów lokalnych w Petersburgu.

Listę prorosyjskich działań i wypowiedzi austriackiego polityka bardzo dobrze streszcza wspomniany powyżej raport: „Gudenus od dłuższego czasu proponował prowadzenie prorosyjskiej polityki. Zasugerował wybudowanie szerokotorowej kolei z Moskwy do Wiednia, wielokrotnie domagał się zniesienia sankcji przeciwko Rosji. Kilkukrotnie nawoływał do deportowania czeczeńskich azylantów z Austrii. W 2012 roku Gudenus i odpowiedzialny za sprawy zagraniczne w FPÖ prawnik Johannes Hübner spotkali się z czeczeńskim dyktatorem Ramsanem Kadyrowem w Groznym, by omówić problem czeczeńskich azylantów. Około 30 tys. uchodźców z Czeczenii mieszka i żyje w Austrii, co czyni ich jedną z największych mniejszości etnicznych w tym kraju. [...] W 2014 roku wraz z Johannesem Hübnerem byli uczestnikami moskiewskiej konferencji »Forum dużej rodziny i przyszłości ludzkości« finansowanej przez Fundację św. Bazylego Wielkiego oligarchy Małofiejewa. W trakcie konferencji nazwał Europę »marionetką Brukseli i USA«, za którą musi się wstydzić. Nazywał UE »lobby dla homoseksualistów, którzy mają swoje własne stacje telewizyjne i gazety«. Gudenus przemawiał po rosyjsku"17.

Należy podkreślić jeszcze jeden aspekt działalności Gudenusa, czyli powiązania gospodarcze. Od 2006 roku zarząadzał on firmą Donowan Invest Trading, której właścicielem był obywatel rosyjski Roman Weksler. Sprawa jest o tyle ciekawa, że firma miała siostrzaną spółkę działająca w Rosji: Donowan Invest Trading Rus. Obie firmy zajmowały się handlem bawełną i nie radziły sobie zbyt dobrze na rynku. Tonące w długach sięgających kilkuset tysięcy euro przedsiębiorstwa zostały zlikwidowane ${ }^{18}$. Nie jest to jedyne niejasne powiązanie gospodarcze pomiędzy Rosjanami a politykami FPÖ. Sięgają one nawet do przewodniczącego partii Hanza-Christiana Strache. Posłanka z ramienia wolnościowców Barbara Kappel handlowała rosyjską „wzbogaconą” wodą w firmie Aquabionica. Inwestorem w firmie był Gruzin Lewan Pirweli. Postać ta bezpośrednio łączy się z Strachem. Obaj panowie spotkali się w 2008 roku, by omówić wojnę gruzińsko-rosyjska, po którym to Strache zaczął bronić rosyjskiej wersji wydarzeń ${ }^{19}$. Barbara Kappel obecnie pełni funkcję deputowanej do Parlamentu Europejskiego.

Szczytem współpracy pomiędzy FPÖ a Rosją była wizyta Strache, Hofera, Hübnera oraz Gudenusa w Moskwie w grudniu 2016 roku. Podczas tego pobytu podpisano umo-

16 Ukrainian Ambassador reacts to Austrian politicians visiting occupied Crimea, https://112.international/politics/ukrainian-ambassador-reacts-to-austrian-politician-visiting-occupied-crimea22573.html (dostęp: 7 lutego 2018).

17 L. Győri (red.), Russian Connections..., s. 27-28.

18 Informację o pracy w tej firmie można znaleźć na oficjalnym profilu Gudenusa jako wiedeńskiego radnego https://www.meineabgeordneten.at/Abgeordnete/johann.gudenus (dostęp: 7 lutego 2018).

19 Zarówno o powiązaniach Gudensua, Kappel, jak i Strache można przeczytać w artykule: H. Höller, Moskaus blaue Freunde, http://www.zeit.de/2014/40/russland-oesterreich-kreml-fpoe (dostęp: 7 lutego 2018). 
wę o partnerstwie z partią Władimira Putina Jedna Rosja. Sygnatariuszami byli przewodniczący Heinz-Christian Strache oraz Siergiej Żeleźniak. Warto wspomnieć, że Żeleźniak jest na unijnej liście osób objętych sankcjami ${ }^{20}$. Celem porozumienia miało być odbywanie wspólnych konsultacji, wymiana informacji, organizacja konferencji oraz promowanie rozwoju gospodarczego. Najciekawiej brzmiącym elementem współpracy jest dbanie o wychowywanie młodszych pokoleń w duchu patriotyzmu oraz zadowolenia z wykonywanej pracy.

Trzeba jednak przyznać, że w ciagu poprzedniego roku oficjalna współpraca nie uległa intensyfikacji w porównaniu z latami poprzednimi. Być może należy zrozumieć podpisanie tej umowy jako akt dokonany na potrzeby polityki wewnętrznej. W Rosji można pokazać, że następuje przełamanie izolacji, natomiast w Austrii wolnościowcy pokazują, że są zdolni do prowadzenia odpowiedzialnej międzynarodowej polityki. Jednym z elementów kampanii prezydenckiej Norberta Hofera było twierdzenie, że jego atutem jest umiejętność przyjaznej rozmowy zarówno z Donaldem Trumpem, jak i Władimirem Putinem i przez to możliwość odgrywania większej roli na arenie międzynarodowej.

\section{Pozostałe wpływy}

Rosyjskie wpływy na radykalną prawicę nie ograniczają się tylko do FPÖ. Kolejną organizacją mocno przesiąkniętą prorosyjskimi postawami jest austriacki oddział Ruchu Identytarystów - Identitäre Bewegung Österreichs, IBÖ. Ta licząca kilka tysięcy osób organizacja przeciwstawia się liberalizmowi, multikulturalizmowi, islamizacji i kosmopolityzmowi. Ideologiczną podstawą jest rasistowskie przekonanie, że ludzie różnych kultur nie powinni się mieszać. Jednocześnie ugrupowanie to jest silnie prorosyjskie i antyamerykańskie. W swojej działalności identytarianie skupiają się przede wszystkim na happeningach politycznych, takich jak przerywanie wykładów oraz przedstawień teatralnych czy okupacja instytucji zajmujących się pomocą dla migrantów i uchodźców $^{21}$. Jednym $\mathrm{z}$ formacyjnych elementów ruchu identytarian jest filozofia Aleksandra Dugina i pochwała rosyjskiej walki z terroryzmem oraz próba wywalczenia przez Rosję miejsca w policentrycznym świecie. Czołowym działaczem i organizatorem środowiska identytarian jest Alexander Markovics. Postać ta kieruje uwagę na działalność Instytutu Suworowa w Wiedniu, gdzie jest częstym gościem wygłaszającym odczy$t^{22}$. Instytut Suworowa na pierwszy rzut oka prowadzi typową działalność promująca język i kulturę rosyjską (w tym sztukę walki - Systema). Jednakże Dokumentationsarchiv des österreichischen Widerstandes (DÖW) wskazuje na silne połączenia Instytutu

20 R. Goncharenko, Putin's friends' in Austria's right-wing FPÖ achieve strong election result, http://www.dw.com/en/putins-friends-in-austrias-right-wing-fp $\% \mathrm{C} 3 \% \mathrm{~B} 6$-achieve-strong-election-result/a-40960928 (dostęp: 7 lutego 2018).

21 Więcej o działalności Ruchu Identytarian można przeczytać w raporcie austriackiego centrum dokumentujacego opór przeciwko nazizmowi (Dokumentationsarchiv des österreichischen Widerstandes (DÖW). Organizacja ta dokumentuje także działalność ruchów radykalnie prawicowych w Austrii, http://www.doew.at/erkennen/rechtsextremismus/neues-von-ganz-rechts/archiv/mai-2014/ rechtsextreme-demonstrieren-in-wien-identitaere-bewegung-oesterreich (dostęp: 7 lutego 2018).

$22 \mathrm{https} / / /$ alexandermarkovics.at/cv/ 
Suworowa $z$ radykalna prawica. Pracujący w Instytucie Patrick Poppel utrzymuje kontakty nie tylko ze środowiskiem identytarian, neonazistami, ale także $\mathrm{z}$ wspomnianym już Gudenusem ${ }^{23}$. Członkowie paramilitarnych organizacji czy sympatycy ruchów neonazistowskich często korzystają z nauki Systemy - sztuki walki wykorzystywanej przez rosyjskie oddziały Specnazu.

Inne środowiska podatne na wpływy z Rosji to chrześcijańscy fundamentaliści oraz kryjące się na forach internetowych koła rasistów. Trudno jednak dokładnie określić, jak liczne są te zgrupowania, niemniej jednak strona rosyjska jest w stanie je penetrować z dość dużą łatwością. Jeszcze trudniej jest określić działalność rosyjskich szpiegów i agentów wpływu. Regularnie temat słabości austriackich służb specjalnych, a zwłaszcza kontrwywiadu, pojawia się w mediach. Austria ze względu na swoją historię państwa-mostu pomiędzy wschodem a zachodem ma zachowane rozbudowane struktury szpiegowskie mocarstw, takich jak USA, Anglia, Rosja czy Chiny. To właśnie w Wiedniu dokonano jednej z większych wymiany złapanych szpiegów pomiędzy USA a Rosją w 2010 roku. Wśród wymienianych była słynna Anna Chapman ${ }^{24}$. Minimalne szacunki mówią o działalności ponad 7 tys. szpiegów w samej stolicy Austrii.

\section{Podsumowanie}

Powyższe zestawienie pokazuje, że Austria jest państwem pod silnymi wpływami rosyjskimi. Przynajmniej w porównaniu z innymi europejskimi krajami. Czynnikami sprzyjającymi takiemu stanowi rzeczy jest historia Austrii i zimnowojenna próba balansowania pomiędzy Związkiem Radzieckim a państwami NATO. Można mówić o ugruntowanych prorosyjskich tradycjach w Austrii, w szczególności gdy chodzi o głównie dwie partie polityczne. Ciekawy proces zaszedł w przypadku tzw. trzeciego obozu - radykalnej prawicy, która kultywując pangermańskie i nazistowskie tradycje stała na antyrosyjskim (i antykomunistycznym) stanowisku. Radykalny zwrot w stronę Rosji to dopiero kwestia ostatniej dekady i przewodnictwa Heinza-Christiana Strachego. Bez wątpienia FPÖ jest dziś najbardziej prorosyjską partią na europejskiej arenie politycznej, wyprzedzająca nawet francuski Front Narodowy, któremu udowodniono przyjmowanie funduszy od Rosjan. Większość głównych liderów FPÖ jest bezpośrednio zaangażowana w kontakty z partią Jedna Rosja i proputinowskimi oligarchami. Najsilniej wyróżniającą się i zarazem najmocniej uwikłaną postacią jest polityk Johann Gudenus.

O ile ÖVP i SPÖ podchodzą do kwestii rosyjskiej pod płaszczykiem pragmatyzmu i interesów gospodarczych, to FPÖ widzi w Rosji sojusznika ideowego czy nawet powinowactwo cywiizacyjne. Wpływy rosyjskie nie ograniczają się tylko do partii politycznych. Austria opleciona jest wiankiem firm (Sbierbank) i organizacji pozarządowych,

23 F. Schmid, M. Sulzbacher, Sputnik, FPÖ, Identitäre: Russisch-rechtes Rendezvous in Wien, https://derstandard.at/2000042003825/Sputnik-Gudenus-Identitaere-Russisch-rechtes-Rendezvous-in-Wien (dostęp: 7 lutego 2018).

24 D. McErloy, Vienna named as global spying hub in new book, https://www.telegraph.co.uk/ news/worldnews/europe/austria/11003898/Vienna-named-as-global-spying-hub-in-new-book. html (dostęp: 7 lutego 2018) oraz W. Theuretsbacher, In Wien residieren 8000 Spione, https://kurier.at/chronik/wien/in-wien-residieren-8000-spione/75.669.611 (dostęp: 7 lutego 2018). 
które służą nie tylko do transferów pieniężnych (niezbyt w Austrii potrzebnych), ale raczej do organizacji i konsolidacji prorosyjskich środowisk. Rosjanie nie ograniczają się tylko do ekstremistów, rasistów czy religijnych fundamentalistów, czego przykładem są silne wpływy w Fedralnej Izbie Gospodarczej. Trzeba jednak podkreślić, że specjalne i bliskie relacje między Austrią i Rosją nie wynikają wcale z intensywnej wymiany handlowej. Obydwa państwa nie są dla siebie żadnymi ważnymi partnerami. Powiązania mają przede wszystkim charakter polityczny, po części wynikający z historycznej roli Austrii jako pomostu między Wschodem i Zachodem, ale de facto oparte są one na pozytywnym ustosunkowaniu się Austriaków do Rosji. Austria stanowi także najważniejsze mniejsce spotkań dla prorosyjskich polityków z całej Europy, na parkietach corocznych, wiedeńskich bali. Do tego dochodzą powiązania i wypływy, które nie są łatwe do wyśledzenia, takie jak np. działalność służb specjalnych. Dużo wysiłku należałoby również włożyć w prześledzenie bardziej pośrednich kontaktów i relacji, np. poprzez polityków i organizacje węgierskie. Nie ulega jednak wattpliwości, że nowo powstały rząd koalicyjny ÖVP i FPÖ Sebastiana Kurza, w którym wicekanclerzem jest Heinz-Christian Strache, będzie jednym z najbardziej prorosyjskich rządów na kontynencie europejskim. Biorąc pod uwagę rosnące napięcia pomiędzy Rosją a kolejnymi państwami Zachodu, Austria może okazać się dla Rosji wartościowym sojusznikiem.

\begin{abstract}
Russian influences in Austria after the Ukrainian crisis in 2014

The author focuses on a multifaceted description of Russian influences in Austria. Firstly, he summarises the narrative that is being spread by institutions tied to Russia and then copied by Austrian mainstream media. Secondly, he focuses on institutional and personal connections with Russia, putting a special emphasis on the role played by the radical right in Austria.
\end{abstract}

Keyword: Austria, Russia, influences, propaganda. 